\title{
Does the Use of English-language Questionnaires in Cross-national Research Obscure National Differences?
}

\section{Anne-Wil Harzing}

University of Melboume, Australia

With the following country collaborators: ${ }^{1}$

Austria: Iris Fischlmayr fohannes Kepler University, Linz

Brazil: Maria Ester Freitas Escola de Administração de Empresas de São Paulo

Bulgaria: Mila Lazarova Simon Fraser University (Canada)

Chile: Leonardo Liberman Yaconi Queensland University of Technology (Australia)

China: Ying Zhu University of Melbourne (Australia)

Denmark: Mikael Søndergaard University of Southern Denmark

Finland: Rebecca Piekkari Helsinki School of Economics

France: Cordula Barzantny Groupe ESC Toulouse Business School, Arizona State University (USA) Germany: Katrin Wittenberg University of Bradford School of Management (UK)

Greece: Barbara Myloni Athens University of Economics and Business

Hong Kong: Wai-Ming Mak Hong Kong Polytechnic University

India: Srabani Roy Choudhury International Management Institute

Japan: Linda Viswat Otemon Gakuin University

Lithuania: Audra Mockaitis Vilnius University; Laura Salciuviene Kaunas University of

Technology

Malaysia: Janaka Chee Kong Low University of Science Malaysia

Mexico: Maria Soledad Gomez Lopez ITESM

Netherlands: Ayse Saka University of Groningen; Deanne Den Hartog Erasmus University

Poland: Aleksandra Grzesiuk West Pomeranian Business School

Portugal: Francisco B. Castro CEMPRE, Faculdade de Economia do Porto, Universidade do Porto Russia: Graham Roberts Groupe ESC Lille/Lille Graduate School of Management (France)

Spain: Ignacio Martínez University of Navarra 
Sweden: Lena Zander, Giara Sutton and Laurence Romani IIB, Stockholm School of Economics

Taiwan: Wen-Kuei Liang Tatung University

Turkey: Ayda Uzuncarsili Soydas Istanbul Commerce University; Gozde Yilmaz Kocaeli University

$U K$ : Alan Feely Aston Business School

USA: Miguel R. Olivas-Luján ITESM (Mexico); Martha Maznevski IMD (Switzerland)

ABSTRACT Cross-national research is plagued by many obstacles. This article focuses on one of these obstacles: the fact that research in more than one country usually involves respondents with different native languages. We investigated whether the language of the questionnaire influences response patterns. More specifically we tested whether responding in a common language (English) leads to a homogenization of responses across countries, hence obscuring national differences. We tested this hypothesis with a sample of 3419 undergraduate students in 24 countries. Half the students in each country received an English-language questionnaire, while the other half received the same questionnaire in their native language. Three types of questions were included in the questionnaire: questions about cultural norms and values, questions about characteristics of the ideal type of jobs that students would prefer after graduation, and questions about the reasons for choosing particular electives in their studies. Differences across countries were considerably smaller for nearly all questions when the English-language questionnaire was used. Consequences and recommendations for cross-national research and management are discussed.

KEY WORDS $\bullet$ international research $\bullet$ language $\bullet$ research methods

Cross-national research is plagued by many problems (for an overview see for instance Singh, 1995; Usunier, 1998; van de Vijver and Leung, 2000). One of these problems is the fact that when doing research in more than one country, the researcher usually encounters respondents with different native languages. When confronted with a linguistically diverse population, a researcher can translate the questionnaire into as many languages as necessary - which is the only option if respondents are monolingual or if there is no shared second language among them. Brislin (1986) offers a set of recommendations for translation of research instruments, but questionnaire translation is not an unambiguous process and might be timeconsuming and expensive. Fortunately, respondents with sufficient language capabilities might be able to respond to the questionnaire in its original language (usually English). However, this leads to another question: could the language of the questionnaire influence a person's response?

There are two different conceptions of the role of language in the study of cross-national differences that might be able to offer an answer to this question: the Whorfian and the linguistic positions (Hulin and Mayer, 1986). According to the extreme Whorfian position, individuals who speak different languages live in different worlds, rather than living in the same world with different labels for objects, events and concepts. This position is based on the Sapir-Whorf hypothesis that sees language as a filter between an individual and his or her environment. Language has such a strong impact that cross-language research is virtually impossible. According to the extreme linguistic position, very high fidelity translations from a source to a target language would provide a sufficient basis for cross-language and cross-national assessments and comparisons because languages are 
simply linguistic symbols for common terms and can be translated into an equivalent set of symbols, a different language, with little loss of meaning (Brislin, 1980, cited in Hulin and Mayer, 1986).

Although neither of these positions is likely to be accurate in its extreme form, a less extreme version of the Whorfian hypothesis suggests that the language of the questionnaire might influence people's responses. Since language and culture are interrelated, this influence is especially likely when the instrument assesses cultural norms and values. Yang and Bond (1980) have termed this process 'cultural accommodation'. Respondents will (subconsciously) accommodate their answers to the language in question and hence when respondents from two or more language groups reply to a questionnaire in the same language, differences between these two groups will be smaller than when they reply to a questionnaire in different languages. Previous research has found some evidence that the language of a questionnaire can influence individuals' responses in this way (see for instance Earle, 1969; Botha, 1970; Bond and Yang, 1982; Candell and Hulin, 1986; Schemerhorn, 1990; Ralston et al., 1995; Erdener et al., 1996; Harzing et al., 2002). This article will focus on testing this hypothesis in a more controlled setting and on a larger scale than has been done so far.

\section{Literature Review}

Studies on the impact of language on response patterns have focused on one of two approaches: within-participant comparisons and between-participant comparisons (Sanchez et al., 2000). The within-participant approach presents the same questionnaire in two different languages to every respondent. The between-participant approach splits up the group of respondents and each respondent answers the questionnaire in only one language.

Results for within-participant compari- sons are mixed. Earle (1969) and Botha (1970) found significant differences between language versions, while Erdener et al. (1996) found significant differences for a sub-group of their sample only. Katerberg et al. (1977), Tyson et al. (1988) and Sanchez et al. (2000) did not find any differences between language versions. However, it is possible that respondents have made an effort to remember their earlier responses. Separating the administration of the questionnaire in time in order to address this problem - as was done in many of these studies - allows for confounding variables to intervene. Depending on the design of the study it might also lead to a much smaller sample, since some respondents might decline participation in the second study.

The between-participant approach eliminates the potential consistency bias, but puts heavy demands on the comparability between samples. Four studies that applied this approach (Bond and Yang, 1982; Harzing et al., 2002; Ralston et al., 1995; Schemerhorn, 1990) found differences between language versions, while one study (Candell and Hulin, 1986) found only very minor differences. Ralston et al.'s (1995) study illustrates a major drawback of the between-participant approach in comparison with the withinparticipant approach: it is very difficult to find samples that are matched on all other characteristics apart from the language of the questionnaire (Sanchez et al., 2000). Respondents might differ in terms of demographic characteristics, their position in the company, the type of company they work for, and so on. Although some of these characteristics were measured in the Ralston et al. (1995) study, they were not included in the analysis. ${ }^{2}$

\section{Our Study's Contribution}

We have chosen to use the between-participant approach in our study, since we feel that the 'consistency' problem associated with the within-participant approach would hinder meaningful comparisons. However, we have 
made every effort to avoid the problems associated with the between-participant approach by eliminating self-selection and matching respondents very closely. In addition, our study will improve on earlier studies in several ways.

First, like Harzing et al. (2002), we include both questions that relate to cultural values and questions that are more neutral. Most earlier studies focused on only one category of questions, either cultural values (Earle, 1969; Botha, 1970; Bond and Yang, 1982; Tyson et al., 1988; Ralston et al., 1995) or questions dealing with organizational issues such as job description and organizational commitment (Katerberg et al., 1977; Candell and Hulin, 1986; Sanchez et al., 2000). Generally, studies focusing on cultural values found a response effect, while studies focusing on more neutral questions did not.

Second, our study compares English with no fewer than 18 other languages in 24 countries. It therefore includes a much wider range of countries and languages than previous studies that usually focused on a comparison between English and one other language only: Chinese (Earle, 1969; Bond and Yang, 1982; Schermerhorn, 1990; Ralston et al., 1995), Spanish (Katerberg et al., 1977; Sanchez et al., 2000), Afrikaans (Botha, 1970; Tyson et al., 1988) or French (Candell and Hulin, 1986). Harzing et al. (2002) included six languages in seven different countries. However, this study used a comparison group of UK students that was not ideally matched with the other respondents and did not control for differences in demographics and English-language competence. It also included only two nonEuropean countries.

Our current study includes North European (Austria, Denmark, Finland, Germany, the Netherlands, Sweden), South European (France, Greece, Portugal, Spain), Central or East European (Bulgaria, Lithuania, Poland, Russia, Turkey), Latin American (Brazil, Chile, Mexico) and Asian (China, Hong
Kong, India, Japan, Malaysia, Taiwan) countries. It will therefore allow us to test whether the language of the questionnaire influences response patterns with a much larger and more varied sample. Our study's main hypothesis follows, and details of our study's design can be found in the next section.

Hypothesis 1: Differences between countries will be larger for native-language questionnaires than for English-language questionnaires.

\section{Study Design and Methodology}

\section{Instrument}

As indicated, the aim of our study is to assess whether the language of the questionnaire has an impact on the way people respond to the questions included in it. Because of the interaction between language and culture, response differences are more likely for questions that relate to cultural values than for those that are more neutral. Our instrument therefore included examples of both types of questions. Since our population consisted of students, our neutral questions related to reasons for choosing electives. In addition to cultural values and elective choice questions, a third set of questions was introduced that asked students to assess the importance of various characteristics of their ideal job after graduation. As these questions refer to cultural values, they might also be expected to show response differences.

In designing the instrument we followed best practices in cross cultural research (as recently summarized by Schaffer and Riordan, 2003), such as using back-translation, avoiding colloquial language, using short and simple sentences, repeating nouns instead of using pronouns wherever possible and considering the national collaborators' perspectives in designing the questionnaire. This section first discusses the three types of questions, then the translation procedures that we used to ensure conceptually equivalent translations. 
Measures To measure cultural values, we used a revised version of the Cultural Perspective Questionnaire (Maznevski et al., 2002), which is based on the culture framework presented by Kluckhohn and Strodtbeck (1961). Because of constraints in terms of questionnaire length, we chose to focus on only two of the six cultural dimensions: 'activity' and 'relationships', each with three variations. The three variations of basic modes of activity are doing, being and thinking. The three types of naturally occurring relationships among humans are individualism, collectivism, and hierarchy. Kluckhohn and Strodtbeck clearly identified individuals as the 'holders' of the preference for variations, whereas the cultural pattern was defined by the aggregation of individuals' preferences. We can therefore make hypotheses and test them at the individual level of analysis. Each of the variations was measured with seven single-sentence items and respondents were asked to record their strength of agreement with each, on a Likert scale from 1 (strongly disagree) to 5 (strongly agree). ${ }^{3}$

As a representative for neutral questions, we asked students for the rationale in their selection of electives, providing a range of eight predefined reasons. Even though answers to these questions might differ across countries, we do not expect them to differ systematically between languages in one country, since these questions would not appear to be clearly related to cultural values.

The third set of questions asked students to assess the importance of various characteristics of their ideal job after graduation and was adapted from Sirota and Greenwood (1971) and Hofstede (1980). A total of 18 questions were included in the questionnaire. All questions are listed in Table 1 (see Results section).

Translation The questionnaire was designed in English and was pilot tested in the UK in October 2000. This pilot test resulted in the replacement of some items for the cultural dimensions and the introduction of the ideal job questions. The pilot study coincided with a discussion among the first eight country collaborators about translatability of items. Several items that proved to be difficult to translate were replaced. Subsequently, bilingual country collaborators were responsible for the translation of the original English questionnaire. Translations were conducted using translation-backtranslation procedures. The translator and back-translator were separate individuals who did not enter into a discussion until after they had finished their translations, at which time discussions between them usually resulted in some changes. Where difficulties remained, a third bilingual person was consulted. The back-translated versions were verified by the project coordinator for consistency across languages, which usually resulted in further changes and discussions between the translator and back-translator. For several of the European languages the project coordinator provided independent verification of the translated versions.

Although, as in any multi-country study, it is very difficult to guarantee translation accuracy with absolute certainty, we are quite confident that the resulting questionnaires are equivalent in meaning across languages. Further, any potentially remaining translation inaccuracies would be attenuated by two factors. First, we are looking at response patterns for a total of 68 items and hence translation inaccuracies in one item would not have a major impact on overall results. Second, we are looking at overall response patterns across 24 countries, so that any translation inaccuracies for specific languages would again not have a major impact on overall results.

\section{Sample and Questionnaire Administration}

The project coordinator recruited country collaborators through personal contacts and networking at professional conferences such 
as the Academy of Management. Once the project had started, several researchers contacted the project coordinator directly offering to collect data in their country. All country collaborators received a 15-page document containing very detailed instructions about the aim of the study; items and constructs; results of the pilot study; translation, data collection and data entry procedures; as well as agreements about coauthorship; and they all received access to the final data set. A document with personal introductions for all collaborators was prepared to promote group cohesion and facilitate networking among collaborators.

We used university students as respondents in our study. When studying culture, differences between students and other sample types, such as managers, tend to be unimportant (Triandis et al., 2001; Keating et al., 2002), hence students can be used as a good approximation of the general survey population in management studies. Although we would of course expect students to reply differently to the elective and ideal job questions than managers, we have no reason to assume that there would be a difference between students and managers in terms of their response to different language questionnaires. Furthermore, in order to isolate the language effect from a multitude of possible intervening factors, we need samples that are comparable in every aspect except for the language of the questionnaire. It is very difficult to realize this with a managerial sample, next to impossible to do this in a crosscountry comparison, and completely infeasible in a comparison across 24 countries.

Respondents were final year university students following a course in business administration, business and management, commerce, or a similar subject. ${ }^{4}$ They were generally between 21 and 22 years old. The gender distribution varied from $27 \%$ female in India to $77 \%$ female in Hong Kong. International students were excluded from our sample, so that our comparisons only included students that could be assumed to be representative of the country they studied in. The resulting sample sizes ranged from 85 for Russia to 210 for the Netherlands, but for most countries were around 100. Data were collected between March 2001 and April 2003.

Collaborators were instructed to make sure that the different language versions were randomly distributed. In most countries English and native language questionnaires were distributed in the same class. In the remaining countries, different classes of the same or a related module were used to separate English and native language questionnaires. Respondents were not allowed to choose which language version they were given and were not told about the aim of the study until after they completed the questionnaire. They were informed the study involved a comparison of values and opinions of students across countries. Equal numbers of English-language and native-language questionnaires were distributed.

To verify whether collaborators had succeeded in the randomization process, we tested whether the two language groups differed systematically on the question: 'How typical do you consider your view to be of people who live in the country in which you were born?' None of the 24 countries showed a significant difference between the language versions on the 'typical view' question, which shows that there were no systematic differences between the two language samples. However, in some of the countries there was a difference in age and gender distribution between the different language versions. We therefore included age and gender as control variables in our statistical analysis. Since different levels of English language competency might also impact on response patterns, this variable was included as a control variable as well. English language competence was measured by asking respondents how often they read English (daily, several times a week, once a week, once a month or less). It was 
thought that this was a more reliable indicator than a self-assessed level of competence, which moreover might be influenced by the language of the questionnaire (i.e. higher level of perceived English-language competence when replying to an English-language questionnaire).

\section{Results and Discussion}

We hypothesized that replying in a common language (English) would lead to a homogenization of responses across countries, hence obscuring national differences. This hypothesis was tested using SPSS's General Linear Model (GLM) procedure. This is a technique that provides regression analysis and analysis of variance for one dependent variable by one or more factors and/or variables. In contrast to linear regression analysis, the GLM technique allows a combination of categorical and continuous independent variables, without the necessity to recode categorical data into individual dummy variables. In contrast to ANOVA analysis, the technique allows for easy inclusion of control variables. Age, gender and English-language competence were included as control variables, while the country of data collection was the independent variable of interest. Using a split data file, the tests were run separately for both language versions (English or native) and each individual question in the questionnaire. Table 1 records the mean and standard deviations for each item as well as the F-values resulting from a comparison across countries in both language versions. It also records the reduction in $\mathrm{F}$-value between the native-language version and the Englishlanguage version and the level of significance of this reduction. It shows that even though there were significant differences between the 24 countries for both the native-language questionnaire and the English-language questionnaire, differences were larger for the native-language questionnaire in all but four of the 68 questions. The increased variance for the English-language version was significant for only one of these four cases. In contrast, the reduced variance that characterized the English-language version for the 64 remaining questions was significant for 58 of them, in most cases at $p<0.001$. So in total, 58 of our 68 items show a significantly reduced variance for the English-language version when compared with the nativelanguage version.

Overall we therefore found a high level of support for our hypothesis. As was expected, overall the homogenization effect was slightly stronger for the cultural values and the ideal job type questions than for the elective questions. However, even for the elective questions, which were expected to be more neutral, a substantial effect was present. And even though the English-language questionnaires still showed significant overall differences between countries, using an English-language questionnaire rendered these differences insignificant for many items when individual countries were compared.

This result has important implications for cross cultural research and hence our understanding of management across cultures. The globalization of the world economy and the increasing importance of multinational companies has made more and more researchers realize that management theories and concepts developed in one part of the world (usually the USA) might not be applicable across borders. In order to find out which theories and concepts are universally valid and which have to be adapted, cross-national research is necessary. However, when these studies are conducted using an Englishlanguage questionnaire, we might mistakenly conclude that differences between countries are rather small or non-significant and that management theories and concepts developed in the USA can be applied across cultures. 
Table 1 Country differences for different language questionnaires controlling for age, gender and English language competence

\begin{tabular}{|c|c|c|c|c|c|}
\hline Question & Mean & SD & $\begin{array}{l}\text { F-value } \\
\text { native }\end{array}$ & $\begin{array}{l}\text { F-value } \\
\text { English }\end{array}$ & $\begin{array}{c}\text { F-value } \\
\text { and } \\
\text { sign. of } \\
\text { difference }\end{array}$ \\
\hline \multicolumn{6}{|l|}{ Activity being } \\
\hline \multicolumn{6}{|l|}{ If you don't like your working environment } \\
\hline It is best to live for the moment & 3.31 & 1.108 & 17.997 & 4.557 & $13.440 * * *$ \\
\hline It is important to do what you want, when you want & 3.58 & .997 & 8.682 & 5.910 & $2.772 * * *$ \\
\hline $\begin{array}{l}\text { It is more important to enjoy life away from work than to } \\
\text { enjoy work itself }\end{array}$ & 2.75 & 1.095 & 6.691 & 3.598 & $3.093^{* * * *}$ \\
\hline $\begin{array}{l}\text { People should take time to enjoy all aspects of life, even if it } \\
\text { means not getting the work done }\end{array}$ & 3.23 & 1.034 & 9.492 & 2.688 & $6.804^{* * * *}$ \\
\hline Quality of life is more important than financial achievement & 4.03 & .936 & 8.679 & 4.368 & $4.311^{* * * *}$ \\
\hline $\begin{array}{l}\text { You shouldn't worry about working when you don't feel } \\
\text { like it }\end{array}$ & 2.59 & 1.025 & 8.974 & 4.064 & $4.910^{* * *}$ \\
\hline \multicolumn{6}{|l|}{ Activity doing } \\
\hline Hard work is always commendable & 3.37 & 1.088 & 12.738 & 8.093 & $4.645^{* * * *}$ \\
\hline It is important to get the job done before relaxing & 3.55 & .999 & 4.423 & 3.835 & 0.588 \\
\hline $\begin{array}{l}\text { Once you set a goal, it is important to work towards it } \\
\text { until it is achieved }\end{array}$ & 4.08 & .778 & 7.440 & 4.684 & $2.756^{* * *}$ \\
\hline $\begin{array}{l}\text { People should work hard and sacrifice enjoyment to } \\
\text { accomplish important things }\end{array}$ & 2.88 & 1.124 & 19.139 & 3.351 & $15.788 * * *$ \\
\hline People who work very hard deserve a great deal of respect & 3.73 & .956 & 6.753 & 2.817 & $3.936^{* * * *}$ \\
\hline Sitting around without doing something is a waste of time & 3.10 & 1.287 & 12.288 & 7.662 & $4.626^{* * *}$ \\
\hline $\begin{array}{l}\text { Time away from work should be used to accomplish } \\
\text { something important }\end{array}$ & 3.34 & 1.051 & 11.566 & 7.967 & $3.599^{* * * *}$ \\
\hline \multicolumn{6}{|l|}{ Activity thinking } \\
\hline $\begin{array}{l}\text { Decisions should be analysed from every possible } \\
\text { angle before they are implemented }\end{array}$ & 3.67 & .982 & 18.686 & 15.991 & $2.695^{* * *}$ \\
\hline $\begin{array}{l}\text { Decisions should be made based on analysis, not } \\
\text { intuition or emotional feelings }\end{array}$ & 2.95 & 1.083 & 16.895 & 11.612 & $5.283^{* * * *}$ \\
\hline It is always better to stop and plan than to act quickly & 3.34 & 1.005 & 14.038 & 12.127 & $1.911^{* * * *}$ \\
\hline $\begin{array}{l}\text { No matter what the situation, it is always worth the } \\
\text { extra time it takes to develop a comprehensive plan }\end{array}$ & 3.27 & 1.010 & 11.558 & 7.069 & $4.489^{* * * *}$ \\
\hline People need to approach life thoughtfully & 4.00 & .780 & 10.190 & 3.751 & $6.439^{* * * *}$ \\
\hline $\begin{array}{l}\text { People should always reflect on the meaning of their } \\
\text { actions carefully }\end{array}$ & 3.74 & .970 & 6.184 & 4.872 & 1.312 \\
\hline The best decision is the most logical one & 2.73 & .999 & 7.360 & 4.939 & $2.421^{* * * *}$ \\
\hline \multicolumn{6}{|l|}{ Relationship collectivism } \\
\hline $\begin{array}{l}\text { Every member of a team has responsibility for all other } \\
\text { members of the team }\end{array}$ & 3.98 & .887 & 12.822 & 3.519 & $9.303^{* * * *}$ \\
\hline $\begin{array}{l}\text { Good team members subordinate their own interests to } \\
\text { those of the team }\end{array}$ & 3.56 & .921 & 5.384 & 3.549 & $1.835^{* *}$ \\
\hline $\begin{array}{l}\text { Individuals should take care of each other more than of } \\
\text { themselves }\end{array}$ & 3.04 & .903 & 7.947 & 4.077 & $3.870^{* * *}$ \\
\hline It is important not to stand out too much in a team & 2.77 & 1.002 & 8.431 & 6.398 & $2.033^{* *}$ \\
\hline One's primary responsibility should be to family and close & & & & & \\
\hline friends, not to oneself & 2.96 & .986 & 11.283 & 4.237 & $7.046^{* * * *}$ \\
\hline People need to identify with a group & 3.67 & .951 & 10.291 & 7.401 & $2.890^{* * * *}$ \\
\hline $\begin{array}{l}\text { Society works best when people make sacrifices for the } \\
\text { good of everyone }\end{array}$ & 3.62 & .965 & 11.632 & 5.697 & $5.935^{* * * *}$ \\
\hline
\end{tabular}


Table 1 Continued

\begin{tabular}{|c|c|c|c|c|c|}
\hline Question & Mean & $\mathrm{SD}$ & $\begin{array}{l}\text { F-value } \\
\text { native }\end{array}$ & $\begin{array}{l}\text { F-value } \\
\text { English }\end{array}$ & $\begin{array}{c}\text { F-value } \\
\text { and } \\
\text { sign. of } \\
\text { difference }\end{array}$ \\
\hline \multicolumn{6}{|l|}{ Relationship hierarchy } \\
\hline A hierarchy of authority is the best form of organization & 2.61 & .996 & 11.289 & 12.573 & -1.284 \\
\hline $\begin{array}{l}\text { Employees should be rewarded on their hierarchical level } \\
\text { in the organization }\end{array}$ & 3.33 & 1.066 & 10.885 & 5.347 & $5.538 * * *$ \\
\hline $\begin{array}{l}\text { People at higher levels in the organization should make } \\
\text { important decisions for people below them }\end{array}$ & 2.67 & .980 & 7.167 & 4.558 & $2.609 * * *$ \\
\hline $\begin{array}{l}\text { People at higher levels in society should have more } \\
\text { privileges than those at lower levels in society }\end{array}$ & 3.81 & 1.094 & 5.194 & 3.308 & $1.886 * *$ \\
\hline $\begin{array}{l}\text { People at lower levels in a group or organization should } \\
\text { carry out the decisions of people at higher levels }\end{array}$ & 2.70 & .896 & 6.567 & 2.503 & $4.064^{* * *}$ \\
\hline $\begin{array}{l}\text { People at lower levels in an organization should not expect } \\
\text { to have much power }\end{array}$ & 2.45 & .974 & 8.549 & 5.708 & $2.841 * * * *$ \\
\hline $\begin{array}{l}\text { The hierarchy of groups in a society should remain } \\
\text { consistent over time }\end{array}$ & 2.66 & .940 & 12.030 & 8.151 & $3.879 * * *$ \\
\hline \multicolumn{6}{|l|}{ Relationship individualism } \\
\hline Adults should strive to be independent from their parents & 2.66 & .976 & 12.027 & 5.027 & $7.000^{* * * *}$ \\
\hline It is important not to depend on other people & 3.52 & 1.100 & 14.134 & 9.535 & $4.599 * * *$ \\
\hline People's first responsibility is to themselves, not others & 3.39 & 1.071 & 13.404 & 4.619 & $8.785^{* * *}$ \\
\hline $\begin{array}{l}\text { People are expected to put their own needs ahead of } \\
\text { others' needs }\end{array}$ & 3.17 & .970 & 5.998 & 4.356 & 1.642 \\
\hline People should be expected to look after themselves & 3.91 & .791 & 6.009 & 3.474 & $2.535^{* * * *}$ \\
\hline $\begin{array}{l}\text { People should satisfy their own needs before they think of } \\
\text { others' needs }\end{array}$ & 2.81 & .995 & 3.219 & 5.498 & $-2.279 * * *$ \\
\hline People who rely on themselves will be successful & 2.90 & 1.142 & 22.596 & 7.660 & $14.936^{* * *}$ \\
\hline \multicolumn{6}{|l|}{ How important is it in your ideal job to: } \\
\hline Be consulted by your direct superior in his/her decisions & 3.71 & .823 & 4.952 & 6.487 & -1.535 \\
\hline Have a good working relationship with your direct supervisor & 3.93 & .789 & 3.246 & 3.773 & -0.527 \\
\hline Have an element of variety and adventure in the job & 4.03 & .843 & 11.048 & 5.381 & $5.667 * * *$ \\
\hline Have an opportunity for advancement to higher level jobs & 4.21 & .744 & 6.493 & 5.426 & 1.067 \\
\hline Have an opportunity for helping other people & 3.58 & .950 & 8.982 & 6.075 & $2.907 * * *$ \\
\hline Have an opportunity for high earnings & 3.84 & .792 & 14.571 & 8.039 & $6.532 * * *$ \\
\hline Have an opportunity to balance your work and private life & 4.23 & .801 & 5.957 & 5.716 & $0.241 * * *$ \\
\hline Have challenging work to do & 4.00 & .770 & 21.380 & 6.034 & $15.346^{* * * *}$ \\
\hline \multicolumn{6}{|l|}{ Have considerable freedom to adapt your own approach } \\
\hline to the job & 4.07 & .772 & 5.707 & 4.880 & 0.827 \\
\hline Have friendly colleagues who help each other & 4.14 & .751 & 4.586 & 2.400 & $2.186^{* * * *}$ \\
\hline Have little tension and stress on the job & 3.13 & .977 & 7.947 & 3.145 & $4.802 * * *$ \\
\hline Have security of employment & 3.77 & .960 & 12.771 & 10.269 & $2.502^{* * * *}$ \\
\hline \multicolumn{6}{|l|}{ Have the opportunity to share responsibility for a task } \\
\hline with others & 3.34 & .910 & 10.498 & 5.716 & $4.782 * * *$ \\
\hline Have the opportunity to take full responsibility for a task & 3.78 & .918 & 11.022 & 4.985 & $6.037 * * *$ \\
\hline Make a real contribution to the success of your organization & 4.11 & .774 & 10.757 & 7.232 & $3.525 * * *$ \\
\hline Serve your country & 2.88 & 1.185 & 30.291 & 15.545 & $14.746^{* * *}$ \\
\hline Work according to clear and stable rules and regulations & 3.03 & 1.159 & 31.692 & 15.889 & $15.803^{* * *}$ \\
\hline Work in a prestigious, successful company or organization & 3.61 & .991 & 11.108 & 6.367 & $4.741^{* * * *}$ \\
\hline
\end{tabular}




\section{Table 1 Continued}

\begin{tabular}{lrrrrrr}
\hline & & & & & $\begin{array}{c}\text { F-value } \\
\text { and } \\
\text { sign. of }\end{array}$ \\
Question & Mean & SD & $\begin{array}{r}\text { F-value } \\
\text { native }\end{array}$ & $\begin{array}{c}\text { F-value } \\
\text { English } \\
\text { difference }\end{array}$ \\
\hline Why do you choose a particular elective? & & & & & & \\
Because I am interested in the subject & 4.30 & .697 & 8.630 & 5.556 & $3.074^{* * *}$ \\
Because I like the lecturer & 3.33 & 1.043 & 10.549 & 5.397 & $5.152^{* * *}$ \\
Because I think I can get a high mark for it & 3.10 & 1.104 & 16.948 & 15.721 & 1.227 \\
Because it is relevant for my future career & 4.15 & .798 & 7.237 & 3.508 & $3.729^{* * *}$ \\
Because it is scheduled at a convenient time & 3.18 & 1.142 & 19.258 & 14.204 & $5.054^{* * *}$ \\
Because it is less work than other electives & 2.72 & 1.110 & 12.924 & 8.723 & $4.201^{* * *}$ \\
Because my friends are choosing it & 2.15 & 1.045 & 10.449 & 6.303 & $4.146^{* * *}$ \\
Because the lecturer has a good reputation & 3.52 & .956 & 9.352 & 5.048 & $4.304^{* * * *}$ \\
\hline
\end{tabular}

$* * * p<0.001, * * p<0.01, * p<0.05$

\section{Conclusion}

Our study has confirmed the results of earlier studies that found that language has an impact on the way people respond to questions relating to cultural values. It extends earlier studies by confirming this effect for a large number of countries and a range of concepts, while at the same time applying a closer matching of respondents. Overall, our study has shown that a decision on the language of the questionnaire should be a key aspect of any cross-national study design. Where questions comprise an element of culture - and we have shown that this might be the case even with questions that at first glance would be considered neutral - the use of English-language questionnaires might obscure important differences between countries. If differences between countries are of interest in the study design, as they will be in most cross-national studies, researchers seem to have little choice but to accept the cost and inconvenience of questionnaire translation.

\section{Notes}

1 Please note that this list indicates the collaborators' current affiliations, which are not always the universities at which the data were collected. Further, some collaborators were not working at that particular university at the time of data collection either, but enlisted local collaborators in their country of origin to help with the data collection.

2 Assessing the descriptive analysis in Ralston et al. (1995), we find that some of the language differences might have been caused by differences in other variables. Managers who responded to the English version of the questionnaire are closer to the American managers in terms of age, years employed, level of employment and size of the company than managers who responded to the Chinese version.

3 A pilot study was conducted in the UK in November 2000, where we tested different scale anchors, running from 'never' to 'always', but these were not well received by the respondents.

4 The Japanese sample was an exception to this. As it proved difficult to find a sample with sufficient English-language skills, we had to resort to students majoring in English. Though this might impact on our betweencountry comparisons, it should not impact on our between-language comparisons.

\section{References}

Bond, M.H. and Yang, K.-S. (1982) 'Ethnic Affirmation versus Cross-cultural Accommodation. The Variable Impact of Questionnaire Language on Chinese Bilinguals from Hong Kong', Fournal of CrossCultural Psychology 13(2): 169-85. 
Botha, E. (1970) 'The Effect of Language on Values Expressed by Bilinguals', Journal of Social Psychology 80: 143-5.

Brislin, R.W. (1980) 'Translation and Content Analysis of Oral and Written Materials', in H.C. Triandis and J.W. Berry (eds) Handbook of Cross-cultural Psychology: Methodology, vol. 2, pp. 389-444, Boston, MA: Allyn \& Bacon.

Brislin, R.W. (1986) 'The Wording and Translation of Research Instruments', in W.J. Lonner and J.W. Berry (eds) Field Methods in Cross-cultural Research, pp. 137-64, Beverly Hills, CA: Sage.

Candell, G.I. and Hulin, C.L. (1986) 'Crosslanguage and Cross-cultural Comparisons in Scale Translations', fournal of Cross-Cultural Psychology 17(4): 417-40.

Earle, M.J. (1969) 'A Cross-cultural and Crosslanguage Comparison of Dogmatism Scores', Journal of Social Psychology 79: 19-24.

Erdener, C.B., Wongtada, N. and Fagenson. E. (1996) 'The "Dual Response" Phenomenon among Bilingual Subjects in Management Research', Business Research Center Working Papers Series, WP96005, School of Business, Hong Kong Baptist University.

Harzing, A.W.K., Maznevski, M. and country contributors (2002) 'The Interaction between Language and Culture: A Test of the Cultural Accommodation Hypothesis in Seven Countries', Language and Intercultural Communication 2(2): 120-39.

Hofstede, G. (1980) Culture's Consequences. International Differences in Work-related Values. London: Sage.

Hulin, C.L. and Mayer, L.J. (1986) 'Psychometric Equivalence of a Translation of the Job Descriptive Index into Hebrew', Fournal of Applied Psychology 71(1): 83-94.

Katerberg, R., Smith, F.J. and Hoy, S. (1977) 'Language, Time and Person Effects on Attitude Scale Translations', Journal of Applied Psychology 62(4): 385-91.

Keating, M.A., Martin, G.S. and Szabo, E. (2002) 'Do Managers and Students Share the Same Perceptions of Societal Culture?', International Fournal of Intercultural Relations 26: 633-52.

Kluckhohn, F.R. and Strodtbeck, F.L. (1961) Variations in Value Orientations. Evanston, IL: Row, Peterson \& Co.

Maznevski, M.L., DiStefano, J.J., Gomez, C.B., Noorderhaven, N.G. and Wu, P.-C. (2002) 'Cultural Dimensions at the Individual Level of Analysis: The Cultural Orientations Framework', The International Journal of Cross Cultural Management 2(3): 275-98.
Ralston, D.A., Cunniff, M.K. and Gustafson, D.J. (1995) Cultural Accommodation: The Effect of Language on the Response of Bilingual Hong Kong Chinese Managers, Journal of Cross-Cultural Psychology 26(6): 714-27.

Sanchez, J.I., Alonso, A. and Spector, P. (2000)

'Linguistic Effects in Translated

Organizational Measures: A Study of Bilinguals', paper presented at the annual Academy of Management meeting, 4-9 August, Toronto.

Schaffer, B.S. and Riordan, C.M. (2003) 'A Review of Cross-cultural Methodologies for Organizational Research: A Best Practices Approach', Organizational Research Methods 6(2): 169-215.

Schemerhorn, J.R. (1990) 'An Empirical Reminder about Language Effects in Crosscultural Business and Management Research: The Case of Bilingual Subjects', Hong Kong Fournal of Business Management viii: 57-66.

Singh, J. (1995) 'Measurement Issues in Crossnational Research', fournal of International Business Studies 26(3, 3rd Quarter): 597-620.

Sirota, D. and Greenwood, M. (1971)

'Understand Your Overseas Workforce', Harvard Business Review 49(1, Jan-Feb): 53-60.

Triandis, H.C. and country contributors (2001)

'Culture and Deception in Business

Negotiations: A Multilevel Analysis', International fournal of Cross Cultural Management 1(1): 73-90.

Tyson, G.A., Doctor, E.A. and Mentis, M. (1988)

'A Psycholinguistic Perspective on Bilinguals' Discrepant Questionnaire Response', Journal of Cross-Cultural Psychology 19(4): 413-26.

Usunier, J.-C. (1998) International and Cross-cultural Management Research. London: Sage.

van de Vijver, F.J.R. and Leung, K. (2000)

'Methodological Issues in Psychological

Research on Culture', Fournal of Cross-Cultural Psychology 31(1): 33-51.

Yang, K.S. and Bond, M.H. (1980) 'Ethnic Affirmation by Chinese Bilinguals', fournal of Cross-Cultural Psychology 11(4): 411-25.

ANNE-WIL HARZING is Associate Professor in International Management at the University of Melbourne, Department of Management, Faculty of Economics and Commerce, Parkville Campus, Melbourne, Victoria 3010, Australia. [email: anne-wil@harzing.com] 


\section{Résumé}

L'usage de questionnaires en anglais dans les recherches comparées internationales atténue t-il les différences entre pays ? (Anne-Wil Harzing et al.)

La recherche comparée internationale est jalonnée de multiples obstacles. Cet article se concentre sur l'un d'entre eux : le fait que les études conduites sur plusieurs pays impliquent généralement des répondants aux langues maternelles variées. L’objectif est de déterminer si la langue utilisée dans un questionnaire influence les réponses obtenues. Plus précisément, l'hypothèse que l'administration d'un questionnaire dans une seule langue commune (l'anglais) conduit à une homogénéisation des réponses entre pays a été testée, ceci signifiant donc une atténuation des différences internationales. L'étude empirique a été menée sur un échantillon de 3419 étudiants dans 24 pays. La moitié des étudiants de chaque pays a reçu le questionnaire en anglais, l'autre moitié dans leur langue maternelle. Trois types de questions constituaient le questionnaire : des questions sur les normes et valeurs culturelles, sur les caractéristiques de l'emploi idéal type que les étudiants aimeraient trouver après l'obtention de leur diplôme et des questions sur les raisons pour lesquelles ils avaient choisi certains électifs au cours de leurs études. Les différences entre pays se sont avérées être largement inférieures pour la quasi-totalité des questions quand le questionnaire en anglais avait été utilisé. Les conséquences et recommandations pour la recherche et le management comparés en milieu international sont finalement discutées.

\section{摘要}

在跨國調研中使用英語問卷會模糊國別差異嗎?

Anne-Wil Harzing et al.

跨國調研受諸多障礙困擾。本文注重其中之一：一國以上的調研通常涉及使用 不同母語的答卷人這一事實。我們調查過，問卷的語文是否影響答卷模式。更 具體地說，我們試驗過，看使用一種通用語文(英語) 答卷會否導致各國的答 卷雷同，從而模糊國別差異。我們以 24 個國家的 3,419 名本科生為例，試驗過 這一假設。給每國的半數學生一份英語問卷，而給另一半學生母語問卷。問卷 中包括三類問題：文化規範和價值；學生畢業後首選的理想工作的特點；他們 研究選項的理由。使用英語問卷時，幾乎在所有問題答案上都各國相差甚小。 文中討論到有關跨國調研和管理的結果及建議。 